8. Про деякі питання практики застосування норм Цивільного та Господарського кодексів України: інформаційний лист Вищого господарського суду України від 07.04.2008 № 01-8/211. URL : http://zakon5.rada.gov.ua/laws/show/v_211600-08.

9. Уніфіковані правила та звичаї для документарних акредитивів від 01.01.1993. URL : http://search.ligazakon.ua/1_doc2.nsf/link1/FIN203.html.

10. Принципи міжнародних комерційних договорів (Принципи УНІДРУА) від 01.01.1994. URL : https://zakon.rada.gov.ua/laws/show/995_920.

11. «Інкотермс» Офіційні правила тлумачення торговельних термінів Міжнародної торгової палати від 01.01.2000. URL : https://zakon.rada.gov.ua/laws/show/988 007.

12. Ухвала по справі № 904/114/19 / ЄДРСР. URL : http://www.reyestr.court.gov.ua/ Review/79057573.

13. Ухвала по справі № 922/1202/19 / ЄДРСР. URL : http://www.reyestr.court.gov.ua/ Review/82887479. 83618507.

14. Ухвала по справі № 904/2899/19 / ЄДРСР. URL : http://www.reyestr.court.gov.ua/Review/

15. Арбитражный процессуальный кодекс Российской Федерации от 24.07.2002 № 95-Ф3. URL : http://www.consultant.ru/document/cons_doc_LAW_37800.

16. Висновок Головного науково-експертного управління на проект Закону України «Про внесення змін до Господарського процесуального кодексу України, Цивільного процесуального кодексу України, Кодексу адміністративного судочинства України та інших законодавчих актів» (реєстр. № 6232 від 23.03.2017 p.). URL : http://w1.c1.rada.gov.ua/pls/zweb2/ webproc4_1?pf3511=61415.

17. Закон України «Про адвокатуру та адвокатську діяльність» від 05.07.2012. URL : https:// zakon.rada.gov.ua/laws/show/5076-17.

УДК 346.13.(094)

DOI HTTPS://DOI.ORG/10.32844/2618-1258.2019.3-1.4

ОСТАПЕНКО Ю.І.

\title{
КОНЦЕПЦІЯ СТАЛОГО РОЗВИТКУ: КОНЦЕПТУАЛЬНІ ПІДВАЛИНИ СУЧАСНОГО ЗАКОНОДАВСТВА
}

У статті розглянуто концептуальні основи Концепції сталого розвитку та обгрунтована доцільність впровадження останніх як концептуальний базис сучасного законодавства і системи права в цілому. Досліджено загальні складові частини Концепції сталого розвитку. Встановлено, що наявний стан екологічної ситуації призводить до висновку, що Концепція сталого розвитку - це безальтернативний шлях для національного та міжнародного законодавства; та, відповідно, остання повинна бути прийнята як окремий нормативний акт як на рівні кожної окремої держави, так і на рівні міжнародних нормативів міжнародних організацій та міжнародних об'єднань. Визначено, що подальше функціонування світової господарської системи на наявних засадах може відбуватися тільки на головуючих засадах відповідної Концепції. Обгрунтовано, що основні засади Концепції сталого розвитку пов'язані з господарською діяльністю, відповідно, формують новий шлях економіко-правового механізму господарювання в розрізі стратегії сталого соціально-економічного розвитку, що у своїй основі має екологізацію, адекватну технологізацію економічної діяльності як такої та разом із цим адекватно поєднує потенціал подальшого розвитку одночасно зі збереженням навколишнього природного середовища.

(C) ОСТАПЕНКО Ю.І. - кандидат юридичних наук, асистент кафедри господарського права (Національний юридичний університет імені Ярослава Мудрого) 
Зазначено, що Концепція сталого розвитку є базовою матрицею концентрації економічної стратегії держави, вона потребує відповідної трансформації господарсько-правової політики, де основним завданням господарсько-правової політики в умовах сталого розвитку є створення спеціальних правових режимів стимулюючого характеру для екологізації господарювання для екологічних інвестицій та екологічних інновацій у сфері господарювання з диференціацією відповідних режимів відповідно до проблематики безвідходних технологій, енергозберігаючих технологій, альтернативної електроенергетики i, зокрема, у сферах, пов'язаних із відходами реструктуризації національної економіки в напрямі подальшої екологізації, суттєвої активізації інноваційної діяльності у сфері екологічного господарювання тощо. Екологізація господарського права $є$ ключовим напрямом розвитку господарського законодавства, і його реалізація потребує зусиль як із боку екологоправової та аграрно-правової науки, так і з боку економічної науки.

Ключові слова: концепція сталого розвитку, доктрина сталого розвитку, сталий розвиток.

The article considers the conceptual foundations of the Concept of Sustainable Development and substantiates the feasibility of introducing the latter as a conceptual basis of modern legislation and the system of law as a whole. The general components of the Sustainable Development Concept are explored. It is established that the current state of the environmental situation leads to the conclusion that the Sustainable Development Concept is an alternative path for national and international legislation; and, accordingly, the latter must be adopted as a separate legal act at the level of each individual state, as well as at the level of international standards of international organizations and international associations. It is determined that the further functioning of the world economic system on an existing basis can only occur on the presiding basis of the corresponding Concept. It is substantiated that the basic principles of the Sustainable Development Concept are related to economic activity, respectively, forming a new way of economic and legal mechanism of economic activity in the context of the strategy of sustainable socioeconomic development, which at its core has greening, adequate technologicalization of economic activity as such and with it adequately combines the potential for further development while preserving the environment.

The Sustainable Development Concept is the basic matrix of concentration of the economic strategy of the state, it requires appropriate transformation of the economic and legal policy, where the main task of the economic and legal policy in the conditions of sustainable development is the creation of special legal incentive regimes for greening the economy for environmental investments and environmental investments. in the field of economics with differentiation of the respective regimes according to the problem of waste-free technologies, energy saving technologies, renewable electricity, particularly in areas related to waste restructuring of the national economy and further towards greening significantly enhance innovation in the field of environmental management and more. The greening of business law is a key area of economic law development, and its implementation requires efforts from both environmental law and agrarian and economic science.

Key words: sustainable development concept, sustainable development doctrine, sustainable development.

Постановка проблеми. У другій половині XX ст. світове наукове співтовариство прийшло до усвідомлення необхідності формування нової моделі розвитку цивілізації, здатної протистояти викликам і проблемам сучасного світу, оскільки можливість самознищення людства стала загрозливою реальністю. 3 одного боку, зростає вплив на природу техногенних і антропогенних факторів, що веде до глобальної екологічної кризи. Сьогодні безперечним $є$ факт, що господарська діяльність людини стала головним фактором забруднення природного середовища та основним чинником деградації довкілля. Тож невипадково, що в цілому сучасна екологічна ситуація в Україні на всіх рівнях, як офіційних так і неофіційних, однозначно визначається як 
кризова [1]. Наслідки утворення та особливо накопичення виробничих, побутових та інших відходів $\epsilon$ ключовим чинником екологічної кризи. Зростання обсягів щорічно накопичуваних тільки побутових відходів в Україні у середньому становить 220-250 кг на рік на одну особу, а у великих містах - 330-380 кг. Сміттєзвалища та полігони для їх накопичення налічують 4157 одиниць і спільно займають площу 7,4 тис. га [2]. Багато країн Заходу шукають шлях для вирішення подібних екологічних проблем, що також набули в них кризової гостроти. Відтак як національна, так і світова спільнота зіткнулися із протиріччями між зростаючими потребами людства та світової економіки і водночас обмеженими можливостями біосфери їх забезпечити. Усе це сприяло усвідомленню необхідності теоретичного осмислення змін, що відбуваються, та розроблення наукової концепції подальшого розвитку людства. Такою теоретичною моделлю стала Концепція сталого розвитку.

В основу цієї Стратегії покладено необхідність практичного забезпечення збалансованого вирішення соціально-економічних проблем на підставі збереження життєздатного навколишнього середовища та природно-ресурсного потенціалу не тільки для сьогоднішнього покоління людства, але і для прийдешніх поколінь. Фактично стратегія сталого соціально-економічного розвитку - це концепція, що має у своїй основі екологізацію, в першу чергу, економічної діяльності як такої шляхом формування нового економіко-правового механізму господарювання, що адекватно поєднує потенціал подальшого розвитку одночасно зі збереженням навколишнього природного середовища. Очевидно, що така перебудова може бути здійснена на глибокому інституційному рівні і має досить велику соціальну ціну [1].

Аналіз останніх досліджень і публікацій. Тема концепції сталого розвитку розглядалася в роботах таких учених-економістів, як: А.М. Балашев, Л.П. Гуляєва, Т.А. Кравченко, Т.О. Савостенко, Л.М. Тимошенко та ін. Щодо аналізу останньої у працях правників, то дана концепція була висвітлена частково з боку екологізації та екологічних інновацій Д.Д. Задихайло, аспект екологічного підприємства був висвітлений у працях А.Г Бобкової. Однак у цілому дана тема залишилася поза центром уваги у юристів.

Постановка завдання. Метою цієї статті є аналіз феномену Концепції сталого розвитку та впровадження іiї концептуальних основ до сучасного законодавства.

Результати дослідження. Сучасним трендом, вірніше -концептуальними підвалинами сучасного законодавства $€$ концепція сталого розвитку, яка визнана світовою спільнотою як домінантна ідеологія розвитку людської цивілізації у XXI ст.

Взагалі термін «сталий розвиток» був введений у широке вживання Міжнародною комісією з навколишнього середовища і розвитку, створеної в 1984 р/, яку очолила прем'єр-міністр Норвегії Гру Харлем Брундланд. У доповіді «Наше спільне майбутнє», опублікованій у 1987 р., під сталим розвитком розумівся такий розвиток, який задовольняє потреби теперішнього часу, але не ставить під загрозу здатність майбутніх поколінь задовольняти свої власні потреби [1]. Таким чином, основним завданням концепції проголошувалося досягнення оптимальних результатів розвитку при мінімальному збитку для середовища проживання людства [2].

Конференція ООН із навколишнього середовища і розвитку, що відбулася в Ріо-де-Жанейро в 1992 р., офіційно проголосила Стратегію сталого розвитку людства довготривалою стратегією всесвітнього розвитку. Основні ідеї концепції сталого розвитку можна звести до таких положень: сталий розвиток означає якісні перетворення всіх сфер людського життя; сталий розвиток являе собою синтез глобального і локального розвитку, оскільки неможливо забезпечити стійкість загальносвітового розвитку за нестійкості розвитку його окремих елементів; перехід світової спільноти до сталого розвитку безпосередньо пов'язаний із глобалізаційними процесами, при цьому саме конструктивні елементи глобалізації служать його досягненню; оскільки у структурі глобалізаційних процесів є досить багато дестабілізуючих елементів, що порушують стійкість світового розвитку, актуальним завданням $€$ їх усунення. Слід зазначити, що взаємозв'язок між глобальною економічною та екологічною системами автори концепції сталого розвитку розглядали як найбільш значну проблему [1, с. 115].

Звісно, існує активний аспект реалізації концепції сталого розвитку, де питання активної екологічної регенерації деградованого довкілля у процесі цілеспрямованої спеціальної господарської діяльності, а також проблема активного заміщення ресурсної «брудної» економіки на формат «зеленої» мають виходити на перший план [3].

Модель сталого економічного розвитку грунтується на доктрині сталого розвитку, яка являє собою сукупність ідей, концепцій, положень та постулатів різних наук, зокрема філософії, соціології, економіки, екології, які вже лягли в основу документів ООН та окремих країн (наприклад, 
«Порядок денний на XXI століття», Ріо-де-Жанейро, 1992 р., Конвенція щодо змін клімату, збереження біорозмаїття, боротьби зі злиднями та інше, загальноєвропейські та національні стратегії сталого розвитку країн).

Концепція сталого розвитку розроблялась міжнародним співтовариством поступово, визначаючи принаймні три принципові обов'язкові іiі складові частини: економічне зростання, соціальний прогрес та захист навколишнього середовища. Економічна складова частина чи економічний підхід у концепції сталого розвитку розглядає економіку як безвідхідну, екологічну, енерго- і ресурсозберігаючих систему, націлену на створення екологічно прийнятною продукції. Адже виклик сучасності полягає у вимозі збереження та розвитку сукупного капіталу, за допомогою якого забезпечується створення необхідних для суспільства та індивіда ресурса у вигляді сукупного соціального доходу. Пріоритетною метою є оптимальне використання обмежених ресурсів і використання ресурсозберігаючих технологій. Хоча сьогодні концептуально залишаються невирішеними питання щодо співвідношення завдань збереження природного та людського капіталу. Основним управлінським завданням $\epsilon$, як мінімум, незменшення природного капіталу, а як максимум - створення передумов для зростання відновленої складової частини природного капіталу.

Екологобезпечний соціоприродний розвиток становить основу сталого розвитку, оскільки загострення екологічних проблем становить загрозу для життя всього людства без винятку. Сталий розвиток має забезпечувати збереження і життєздатність природних систем із метою забезпечення глобальної стабільності біосфери планети. Саме поняття природних систем розуміється досить широко, до нього входить навіть створене людиною середовище, наприклад, міста. Основна увага приділяється збереженню здатностей до самовідновлення й динамічної адаптації відповідних систем, до змін, а не до консервації з огляду на уявлення про ідеальний природний стан. У центрі управління сталим розвитком стоїть завдання попередження деградації природних ресурсів, забруднення навколишнього середовища і втрати біологічної розмаїтості.

Таким чином, особливістю концепції сталого розвитку є трактування екологічних проблем насамперед як проблем соціальних. Соціальна складова частина сталого розвитку спрямована на досягнення справедливого розподілу соціальних благ між усіма членами людського суспільства, повноцінне задоволення у всьому світі базових потреб людей в освіті, охороні здоров'я, соціальному забезпеченні тощо, тобто збереження духовного надбання і культурного різноманіття людства, в тому числі скорочення руйнівних конфліктів людства.

Вважається, що для досягнення сталого розвитку необхідно створити більш ефективну управлінську систему, що враховує історичний досвід, заохочує плюралізм та орієнтується на людину як суб'єкт розвитку. Спираючись на розширення варіантів вибору людини як головну цінність, концепція сталого розвитку націлює на упровадження принципу участі кожного індивіда у процесах, які формують його сферу життєдіяльності.

Щодо компонентів моделі сталого розвитку, то сьогодні ними можуть бути соціалізація, державне регулювання, суспільна відповідальність, екологічність, безпека, інформатизація, власність, корпоративна система, ринкове регулювання, алокація ресурсів, інтелектуалізація, транснаціоналізація. Зазначені компоненти виступають не лише як статичні, а насамперед як динамічні механізми організації та функціонування національної, регіональної та світової економіки, поєднання або взаємний вплив яких певним чином дозволяє визначати зміст та структуру моделі.

Слід констатувати, що наявний економічний механізм у світовому масштабі є незмінно орієнтованим на швидкі темпи економічного зростання, зростання рівня споживання та ємкості внутрішніх ринків за рахунок варварської, безвідповідальної експлуатації природних ресурсів. Важливо підкреслити, що названий економічний механізм спричиняє шкоду людству як у контексті безвідповідального вичерпування невідновлюваних природних ресурсів, так і в контексті безпрецедентного за рівнем забруднення навколишнього середовища і в процесі природокористування і подальшої індустріальної переробки сировини.

Відтак сучасний стану природокористування та охорони навколишнього середовища призводить до беззаперечного висновку про вичерпність відновлюваного ресурсу планетарної екосистеми. Подальше функціонування світової господарської системи на наявних засадах може відбуватися тільки за умови розвитку Концепції сталого розвитку та екологічної інноватизації підприємств, а це прямо призводить до розширення виникнення новітніх технологій. Звісно, сучасні технології розробляються в умовах IV промислової революції («Індустрії 4.0») та створюють шлях до нового технологічного укладу, володіють ознакою глобальності як щодо створення, так і щодо моделей їх споживання, а також створюють виклик саме соціальній економіці. Адже 
«Індустрії 4.0» означає все більшу автоматизацію абсолютно всіх процесів та етапів виробництва, від цифрового проектування виробу, створення його віртуальної копії до віддаленого налаштування обладнання на заводі відповідно до технічних вимог для випуску цього конкретного «розумного» продукту. Виробник автоматично замовляє необхідні компоненти в потрібній кількості, контролює їхню поставку, має можливість відслідковувати шлях готового продукту від складу на фабриці та магазину до кінцевого клієнта. Але й після продажу компанія не забуває про свій продукт, як це було раніше у класичній моделі, а контролює умови його використання, може віддалено змінювати налаштування, оновлювати програмне забезпечення, попереджати клієнта про можливу несправність, а під кінець циклу використання - приймати продукт на утилізацію. Разом із тим застосування екологічних технологій нового покоління не може не вплинути на всю екосистему планету, зокрема створення нечуваних за масштабами акумуляторів сонячної енергії на островах Південно-Східної Азії може мати глобальні наслідки через неприродній перерозподіл сонячної енергії, невідомий вплив ії̈ магнітного випромінювання та інших властивостей, невідомих сучасним дослідникам.

Соціальна політика в умовах IV промислової революції - це найважливіший соціальний механізм перетворення суспільства. Держава (загальнодержавний і регіональний рівні), саме громадянське суспільство, приватні корпорації здійснюють як профілактичний, так і компенсаційний соціальний захист, соціальну підтримку. Саме соціальний захист здійснюється в найрізноманітніших сферах суспільного життя: фінансовій, промисловій, сфері послуг: екологічних, медичних, освітніх тощо. В умовах існування держави визначення та обгрунтування соціальної політики в регіоні набуває важливого значення, оскільки саме регіони безпосередньо реалізують на практиці державну політику. Звісно, що соціальна політика є цілеспрямованою й планомірною діяльністю державних та громадських інститутів щодо погодження інтересів різних соціальних верств суспільства у сферах виробництва, розподілу та споживання матеріальних, соціальних і духовних благ. Для того щоб населення схвалювало проведену соціальну політику, спрямовану на підвищення його рівня і якості життя, необхідно визначити та затвердити соціальні орієнтири суспільного добробуту в тісному взаємозв'язку із соціальними інтересами населення, враховуючи можливості конкретних верств населення, ресурсні умови регіонів для надання доступних соціальних послуг.

Роботізація - це тренд економічного розвитку, адже в Конституції України зазначено, що ми - соціальна держава, втім, проблема надання якісного трудового ресурсу у соціальне життя можлива за рахунок штучної зайнятості чи некомерційного господарювання, розвитку корпоративного сектору (як комерційного, так і некомерційного, створення форм, стимулів). Відтак це повинно бути враховано як на рівні господарсько-правової політики, так і на рівні господарського законодавства.

Економічна безпека - різнопланове явище, однак ключовим елементом його характеристики є публічний інтерес, який повинен бути обов'язковою засадою нормотворчої діяльності, і саме прийняття законів повинно сприйматися як базис ключових чинників економічної безпеки.

Сьогодні існує вимога реалізації динамічної функції правового регулювання. Приклад телекомунікаційна сфера, адже розвиток технологій та нових відносин в останній найбільш активний та потребує швидкого реагування законодавства на цю тенденцію.

Висновки. 1. Усвідомлення наявного стану екологічної ситуації призводить до висновку, що Концепція сталого розвитку - це безальтернативний шлях для національного та міжнародного законодавства; відповідно, остання повинна бути прийнята як окремий нормативний акт як на рівні кожної окремої держави, так і на рівні міжнародних нормативів міжнародних організацій та міжнародних об'єднань. Відповідно, подальше функціонування світової господарської системи на наявних засадах може відбуватися тільки на головуючих засадах відповідної Концепції.

2. Створення та необхідність застосування Концепції сталого розвитку співпадає з вибухом IV промислової революції. Утім, економічні інтереси, реалізовані в межах спеціально створених економіко-правових механізмів, можуть бути не тільки проблемою для довкілля, але й механізмом одночасного вирішення екологічних і економічних проблем, зокрема, виробництво продукції, виконання робіт і надання послуг природоохоронного призначення, а також створення екологічних інновацій.

3. Значна частина змісту Концепції сталого розвитку стосується економічного життя суспільства як на національному, так і на глобальному рівні. Необхідність прийняття останньої на законодавчому рівні насамперед для глобального гострого завдання - екологізації господарської сфери, запустить новий реформістський процес у господарському (втім у цілому) законодавстві. 
Адже із прийняттям Концепції на законодавчому рівні необхідним є формування новітньої систематизації усього національного законодавства, враховуючи концептуальні основи останньої. Необхідне урахування основ Концепції сталого розвитку, розроблення і впровадження останніх не тільки на законодавчому рівні, а й на рівні комплексних цільових завдань, стратегій, урядових та місцевих нормативних актів, які стануть основою не тільки трансформації законодавства як такого, але також і трансформаційної діяльності органів державної влади, місцевого самоврядування та економічної системи в цілому.

4. Фактично основні засади Концепції сталого розвитку пов'язані з господарською діяльністю, відповідно, формують новий шлях економіко-правового механізму господарювання в розрізі стратегії сталого соціально-економічного розвитку, що у своїй основі має екологізацію, адекватну технологізацію економічної діяльності як такої та разом із цим адекватно поєднує потенціал подальшого розвитку одночасно зі збереженням навколишнього природного середовища.

Таким чином, все це означає, що Концепція сталого розвитку є базовою матрицею концентрації економічної стратегії держави, вона потребує відповідної трансформації господарсько-правової політики, де основним завданням господарсько-правової політики в умовах сталого розвитку є створення спеціальних правових режимів стимулюючого характеру для екологізації господарювання для екологічних інвестицій та екологічних інновацій у сфері господарювання 3 диференціацією відповідних режимів відповідно до проблематики безвідходних технологій, енергозберігаючих технологій, альтернативної електроенергетики i, зокрема, у сферах, пов'язаних із відходами реструктуризації національної економіки в напрямі подальшої екологізації, суттєвої активізації інноваційної діяльності у сфері екологічного господарювання тощо.

5. Відтак екологізація господарського права $є$ ключовим напрямом розвитку господарського законодавства, і його реалізація потребує зусиль із боку еколого-правової та аграрно-правової науки, а також із боку економічної науки.

\section{Список використаних джерел:}

1. Задихайло Д.Д. Екологічні інновації як форма міжгалузевої конвергенції господарського та екологічного права. Економічна теорія та право. 2016. № 4. C. 145-156. URL : http://nbuv.gov.ua/UJRN/Vnyua_etp_2016_4_15.

2. Задихайло Д.Д. Відносини екологічного господарювання як напрям розвитку законодавства України. Економічна теорія та право. 2017. № 3. С. 96-107. URL : http://nbuv.gov.ua/UJRN/Vnyua_etp_2017_3_11.

3. Задихайло Д.Д. Екологічне господарювання у системі екологічних відносин: проблема правової інституціалізації. Проблеми законності. 2016. Вип. 135. С. 95-103. URL : http://nbuv.gov.ua/UJRN/Pz_2016 135 12.

2. Урсул А.Д., Демидов Ф.Д. С талий соціоприродне розвиток : навч. посібник. Москва : РАГС, 2008. С. 21.

3. Барлибаев Х.А. Людина. Глобалізація. Сталий розвиток. Москва : РАГС, 2007. С. 164-166.

4. Соціологія. Основи загальної теорії : підручник / відп. ред. Г.В. Осипов, Л.Н. Москвичов. С. $701-702$.

5. Корпоративний форум зі сталого розвитку «РIO + 20». Огляд i результати. Pio-де-Жанейро, 21 червня 2012. URL : iblfrussia.org/RioCorpSustForum_Outcome_RUS.pdf. 